\title{
Problems in and Solutions to Oral English Teaching in Rural Middle School—A Case Study in ZhaoCheng Middle School
}

\author{
Yayan $\mathrm{Yu}$ \\ Shanxi Normal University, China
}

\begin{abstract}
As a key skill for language learners, oral communication ability is one of the most important factors to measure one person's overall quality. Being a widely used language, English has become an important communicative medium between countries. However, the purpose of learning English is to communicate. One can really master the language only by putting it into flexible use. However, English teaching in our country has been the problem of "dumb English" for a long time, especially oral English teaching in rural middle school. Due to the various constraints, oral English teaching still takes the traditional teaching methods. Students have no necessary English environment to exercise English. This kind of "dumb English" makes students lack language communicative ability. So it is urgent to improve the oral English teaching in rural school. In this paper, the investigation and questionnaire survey were aimed at investigating students' oral English in the Middle School of Zhaocheng Town in Linfen, Shanxi Province, in order to find out the insufficiency of spoken language and give the recommendations, so as to improve the interest of speaking English for rural students and cultivate their communicative competence in spoken English. Finally, it can promote the students' overall quality and overall performance for our society.
\end{abstract}

Index Terms —oral English, rural middle school, teaching strategies

\section{INTRODUCTION}

With the development of economy and technology, the pace of globalization is very fast and the communication with foreign countries grows frequently. So the oral English becomes more and more important. Only when we communicate frequently with others in English, can we really master English well. But in many Chinese rural places, students in middle schools have a poor oral practice, and most of them cannot speak standard English, though they are taught English in class. The reasons why students in rural middle school are poor in oral English are as follows: the traditional teaching method of English, such as, in order to get higher scores, teachers just want students remember words, sentences and passages without their correct pronunciation; some rural middle schools are short of necessary teaching equipment that can show standard oral English, for example multi-media and English radio. So teachers without standard pronunciation cannot help their student improve oral English; students in rural middle school hardly have opportunities to practice oral English except in class, the limited time. The environment of English is very necessary, but for them, it is very difficult to open mouth.

As an international language, English plays a more and more important role. The central part of learning a language is to communicate, so oral English received more and more attention in China. Thus, the effective approaches to improve oral English for English learners are in urgent need. For example, the government should arrange specialized training for teachers to improve their professional skill, including listening, speaking, reading and writing; it should offer money and equipment to supporting counties' oral English training to make students live in a necessary English environment; and it can appoint some excellent urban teachers to rural middle schools for guiding.

This paper takes one rural middle school for example and another city middle school as contrast, and it is aimed at finding out the insufficiency of spoken language teaching through test, investigation and questionnaire survey and giving the recommendations, so as to improve level of oral English teaching and the interest of speaking English for rural students and cultivate their communicative competence in spoken English. More importantly, it can promote the students' overall quality and overall performance for our society.

\section{LITERATURE REVIEW}

\section{A. An Overview of Oral English in Rural Middle Schools}

The purpose of foreign language learning is to make students have the ability to use language flexibly. Along with the deep development of the curriculum reform, the importance of spoken English is highlighted. The use of oral English is not only an important purpose of learning English, but also the incentive and fun for students to learn English. However, the development of China's urban and rural education is out-of-balanced, and there is a significant gap in the spoken English. 
In terms of hardware and software, there is a gap that cannot be ignored between rural middle school and city middle school. Although students' oral English is being widely concerned in middle school, at present English teaching in rural schools is not paying attention to spoken language training, which lags behind the common level of spoken English. Many students have learned English for many years but they still cannot use English to make a brief conversation. "Dumb English" still exist at a large scale, and in rural middle school, the level of oral English cannot reach to the English teaching goal for communicating and obtaining information. The students' oral English communicative ability in rural middle school overall is poor. From the aspect of teachers, the quality of them in rural middle school is inferior, and there are quite a number of teachers without good oral English and the creative teaching method. In terms of students, students have psychological barrier in the process of learning oral English, and they are not interested in English at all. The problem of rural oral English has drawn much attention to many researchers.

\section{B. Related Research at Home and Abroad}

\section{Studies Abroad}

The famous English linguist L.G. Alexander (1996) thought: "nothing should be spoken before it has been heard. Nothing should be read before it has been spoken. Nothing should be written before it has been read." (p.92). Thus we can see the importance of spoken English. And oral English teaching is to cultivate students to exchange language knowledge into language ability. The purpose of it is to make students gain access to knowledge, information and language by reading and listening, and to process and restructure what have been gained on the basic of prior knowledge and language. Then we can endow new content and output language. Completing the whole process of communication is the final goal (Brown, 2000).

Jeremy hammer (2000) pointed out: the purpose of oral activities is to impart the application competence of language, rather than study a specific part of a language. He thinks students should be able to use it flexibly and complete the task of spoken language. And oral activities can build a platform for students to make students have the practical feeling by communicating with English. At the same time, the oral English learning activities provide feedback to both teachers and students. Many tasks of oral English have high-interest, which helps to stimulate students' interest and enthusiasm and enhance students' self-confidence. All along, foreign language teaching has been biased in favor of "textbook English". The fact is that such a language ability does not achieve the real purpose of communication. Paulson and Bruder (1992) believe that language ability is a part of communicative competence, which is the ultimate goal of learning a language. Students should first master the basic knowledge of language form, but good pronunciation and form does not mean that they have the ability to use them. So it is necessary for students to use appropriate language to cope with the different social environment.

According to Hymes (1972), Communicative language teaching is considered to play a vital role in developing student's communicative competence. It is the communicative language approach that leads to the English teaching methodology.

From those views about oral English at abroad, the author can conclude that the research on oral English and oral English teaching is gradually increasing. And there are many views of research, such as factors of oral English, testing, efficient teaching and so on. But as for the subject, university students are mainly focused.

\section{Studies at Home}

Over the years, the domestic research on oral English teaching has been increasing. Research has also made great theoretical results and practical results, which are helpful for the improvement of spoken English teaching. Domestic research for spoken language teaching mainly focuses on the oral English teaching methods, English environment and strategies.

Under the influence of traditional English teaching method and so on, at present, there are many problems in the process of oral English teaching in China, especially in rural areas. Sun Lifen (2008) investigates the current situation of oral English teaching in rural high school of Hu Bei Province through a questionnaire survey, experiment and interview, and the results demonstrated the feasibility of offering oral English class in rural middle schools after a semester's experiment. This is the creative view for related researches. In this method, a certain amount of repetitions and mechanical practices are emphasized in oral English teaching. In the process of looking for the new method of spoken English teaching, Wen Qiufang tries spoken English teaching through speech laboratory, which shows that when students studies oral English in speech laboratory, students show a higher degree of enthusiasm, but tension and anxiety has been reduced. They are more willing to open mouth to practice English and their oral expressive abilities progress faster (Wen, 1998).

Gao Haihong (2000) studies the relationship between communicative methods and the level of spoken English. The result shows that most of Chinese students rarely use effective strategies in oral English. Huang Biwen (2011) points out "along with the new curriculum reform, comprehensive ability, including, listening, speaking, reading and writing is took seriously. However, there are many problems in rural middle school, we should pay much attention to it" (p.50).

Liu Runqing and Han Baocheng (2008) believe that "in the four language skills, listening, speaking, reading, writing, no matter how stressed the importance of speaking skill is not too much, because one of the purposes of learning language is to communicate. As for social demand for talents, oral English is very important" (p. 150).

Through the analysis of the domestic and foreign related researches on oral English teaching, the author found that the view of domestic and foreign experts and teachers for oral English teaching constantly changes and develops in the 
teaching process. Foreign scholars have accumulated a lot of experience in oral English teaching, and it is clear that the teaching and learning of language cannot be separated from communication and the related English environment. They pointed out that the key of language teaching and learning is to use. The study of oral English education is divided into two directions at home, one is to pay attention to students' integrated development of listening and speaking, reading, writing and translating, but this affects the teaching result, because it involves too widely. The other one is regarding a strategy as a universal method to use in all teaching process, in order to improve the students' oral English ability. The traditional teaching mode of foreign language is just to pay much more attention to language knowledge as much as possible rather than students' oral ability. The scholars of Chinese focus on students' unconscious state of learning English, and it is not mechanical, conscious English knowledge. At the same time, they emphasize the importance of creating English teaching situations.

In this paper, the author adopts the method of comparative study to contrast students' oral English level between a rural middle school and a city middle school, then she draws a conclusion that students' oral English in rural middle school is poorer than students' in city middle school. After this, the author takes the method of questionnaire and interview from the aspects of teachers and students to analyze the problem. The reasons of that can ascribe to the teachers' poor ability, the traditional teaching method and the lack of teaching equipment. Lastly, the author puts forwards related efficient solution to enhance the student' oral English level in rural middle schools.

\section{RESEARCH DESIGN}

\section{A. Research Questions}

Based on the theories of Input Hypothesis, the paper makes an empirical research on oral English teaching in rural middle school and city middle school by questionnaire and interview. The study aims to find the problems of oral English teaching in those schools and the proper countermeasures.

This thesis investigates the oral English teaching and analyses the reasons, and then gives some suggestions for the poor oral English teaching in rural middle school. In order to understand the situation of oral teaching in rural places area, this paper tries to find the problems and countermeasures of oral English teaching in rural places through investigation and questionnaire survey. The author tries to answer the following research questions.

(1) What problems exist in oral English teaching in rural middle schools?

(2) Why is oral English teaching poor in rural middle school?

(3) What effective suggestions can help improve the level of oral English teaching in rural middle school?

\section{B. Subjects}

In order to get a convincing result, this paper made contrastive researches, which are from the Second Middle school in Zhaocheng Rural and Xinli Middle School in Linfen City. The experiment is conducted from September 2015 to December 2015, and the participants of research are from two classes of Grade Seven (Class 52 and Class 47) of Zhaocheng Middle School in Zhaocheng Rural and Xinli Middle School in Linfen City. The two classes are parallel classes of similar level. All of them come from different family and schooling backgrounds. One class (Class 52) is designed as the experimental class, and the other class (Class 47) is the controlled class. These two classes are in different places, one is in the rural, and the other is in the city. The author made a contrastive investigation about oral English in the two places and got the insufficiency of oral English and the reasons in rural middle school.

TABLE 3.2.1

INFORMATION ABOUT THE SUBJECTS

\begin{tabular}{|c|c|c|c|c|c|}
\hline Schools & Class & Number & Male & & Female \\
\hline Xinli & Grade 7,47 & 50 & 24 & & 26 \\
\hline Zhaocheng & Grade7, 52 & 54 & 28 & & 26 \\
\hline \multicolumn{6}{|c|}{$\begin{array}{c}\text { TABLE } 3.2 .2 \\
\text { INFORMATION ABOUT THE SUBJECTS }\end{array}$} \\
\hline \multicolumn{6}{|c|}{$\begin{array}{l}\text { INFORMAIION ABC } \\
\text { Teachers }\end{array}$} \\
\hline Xinli & & \multicolumn{2}{|l|}{ Grade 7} & \multicolumn{2}{|l|}{10} \\
\hline Zhaocheng & & \multicolumn{2}{|l|}{ Grade 7} & 10 & \\
\hline
\end{tabular}

\section{Instruments}

The author takes effort to make the experiment as practical and persuasive as possible, so the instruments used in the research are: two tests, two questionnaires and two open interviews. The test mainly estimates oral English level of students and teachers (See Appendix I). The questionnaires in this paper are divided into teachers' and students' questionnaires (See Appendix II and Appendix III). The interviews are also divided into teachers' interview, which is called interview A (See Appendix IV), and students' interview named interview B (See Appendix V).

\section{Procedures}

\section{Preparation}


At the beginning of last semester, the author had a practice in Second Middle School in Zhaocheng Town. In the process of practice, the author found the problems of oral English teaching and thinks that whether the same problems exist in city middle schools. So the author gained an opportunity to participate in one middle school in Linfen City. It is concluded that there are some differences between middle schools in counties and cities, including oral English teaching methods, teaching equipment and some factors of students.

\section{Questionnaires and Interviews}

According to the observation in both two schools, the author made a spoken English test firstly, and then kept record relatively. Secondly, under that record about the oral English level, she made two questionnaires and two interviews. Thirdly, distribute the questionnaires to 104 students and 20 teachers in two different schools and collect the questionnaires. Later, 10 typical students and 5 teachers were chosen randomly from each school to finish the questions in the interview. Finally, the author made different forms to take contrastive experiment.

\section{Data Collection And Analysis}

\section{A. Data Collection}

In the investigation, 104 students participated in oral English test, 50 students from Xinli Middle School in Linfen City and 54 students from the Second Middle School of Zhaocheng in Zhaocheng Town. Students who got scores (100-80) are good spoken learners, and if students got scores (80-60), they are common spoken learners, and students whose sores are below 60, they are poor spoken learners. Students in city do better in oral English than students in rural, including listening and speaking. For the questionnaires and interview, 104 students and 20 teachers in different schools finished them.

\section{B. Data Analysis}

\section{Analysis of Tests}

In the test, the researcher collected the data of students' listening and speaking scores to analyze the differences between two classes. The result is shown in the following table.

The data are collected as follows: $($ Spoken English $=\mathrm{SE})$

TABLE 4.2.1.1

DATA COLLECTION OF THE TESTS FOR STUDENTS

\begin{tabular}{|l|l|l|l|}
\hline Students & Good SE & Common SE & Poor SE \\
\hline Xinli & 34 & 17 & 3 \\
\hline Zhaocheng & 2 & 15 & 33 \\
\hline
\end{tabular}

TABLE 4.2.1.2

ANALYSIS OF THE LISTENING AND SPEAKING TEST

\begin{tabular}{|l|l|l|l|}
\hline ANALYSIS OF THE LISTENING AND SPEAKING TEST \\
\hline Students & Good SE $(\%)$ & Common SE $(\%)$ & Poor SE $(\%)$ \\
\hline Xinli & 60 & 34 & 6 \\
\hline Zhaochen & 4 & 30 & 66 \\
\hline
\end{tabular}

TABLE 4.2.1.3

DATA COLLECTION OF THE TESTS FOR TEACHERS

\begin{tabular}{|l|l|l|l|}
\hline Teachers & Good SE & Common SE & Poor SE \\
\hline Xinli & 13 & 5 & 2 \\
\hline Zhaocheng & 4 & 8 & 8 \\
\hline
\end{tabular}

TABLE 4.2.1.4

ANALYSIS OF THE LISTENING AND SPEAKING TEST

\begin{tabular}{|l|l|l|l|}
\hline Students & Good SE $(\%)$ & Common SE (\%) & Poor SE (\%) \\
\hline Xinli & 65 & 25 & 10 \\
\hline Zhaochen & 20 & 40 & 40 \\
\hline
\end{tabular}

From Tables, we can see that there was obvious difference between the two schools. Students and teachers in Xinli Middle School have better oral English than students and teachers in Zhaocheng Middle School. 60\% students in city have good oral English, however, students having good oral English in rural account for $4 \%$ and $66 \%$ students have bad oral English. 65\% teachers in Xinli have good spoken English, and just 10\% teachers got bad scores. But in Zhaocheng, teachers who are good at spoken English account for $20 \%$. This result proves students and teachers in rural school have relatively poor oral English.

\section{Analysis of Questionnaires}

At the beginning of the experiment, 104 students are asked to fill out questionnaire, and they must be honest and careful to finish it. They can choose the suitable choice for themselves from the 10 items in the questionnaire. The following table displays the outcome of the questionnaire. 
TABLE 4.2.2.1

THE RESULT OF QUESTIONNAIRE FOR STUDENTS

(EC=experimental class; $\mathrm{CC}=$ control class; $\mathrm{A}, \mathrm{B}, \mathrm{C}$ choice items)

\begin{tabular}{|c|c|c|c|c|}
\hline Item & Class & $\mathrm{A}(\%)$ & $\mathrm{B}(\%)$ & $\mathrm{C}(\%)$ \\
\hline \multirow[t]{2}{*}{1} & EC & 3.5 & 20.5 & 76 \\
\hline & $\mathrm{CC}$ & 70.3 & 22.8 & 6.9 \\
\hline \multirow[t]{2}{*}{2} & EC & 56.8 & 20.6 & 22.6 \\
\hline & $\mathrm{CC}$ & 21.6 & 57.6 & 20.8 \\
\hline \multirow[t]{2}{*}{3} & EC & 4.1 & 30.5 & 65.4 \\
\hline & $\mathrm{CC}$ & 68.4 & 25.2 & 6.4 \\
\hline \multirow[t]{2}{*}{4} & EC & 3.3 & 25 & 71.7 \\
\hline & $\mathrm{CC}$ & 69.1 & 20.9 & 10 \\
\hline \multirow[t]{2}{*}{5} & EC & 11.2 & 33.5 & 55.3 \\
\hline & $\mathrm{CC}$ & 56.2 & 33.7 & 10.1 \\
\hline \multirow[t]{2}{*}{6} & EC & 10.5 & 50.4 & 39.1 \\
\hline & $\mathrm{CC}$ & 68.7 & 24.7 & 6.6 \\
\hline \multirow[t]{2}{*}{7} & EC & 11.5 & 29.3 & 59.2 \\
\hline & $\mathrm{CC}$ & 69.4 & 20.8 & 9.8 \\
\hline \multirow[t]{2}{*}{8} & EC & 2.8 & 25.5 & 71.7 \\
\hline & $\mathrm{CC}$ & 50.6 & 36.7 & 12.7 \\
\hline \multirow[t]{2}{*}{9} & EC & 3.5 & 20.7 & 75.8 \\
\hline & $\mathrm{CC}$ & 49.7 & 45.1 & 5.2 \\
\hline \multirow[t]{2}{*}{10} & EC & 2.1 & 24.1 & 73.8 \\
\hline & $\mathrm{CC}$ & 53.6 & 32.7 & 13.7 \\
\hline
\end{tabular}

From the Table 4.2.2.1, the result of the two classes was very different. And the questions 1 to 10 are intended to know students' oral English learning. Obviously in item 1, nearly 3.5\% of the students in rural middle school often do oral exercise, but $70.3 \%$ of the students in city middle school do it often; as far as result of item 2, approximately $56.8 \%$ of students think they have spent much time in memorizing words and reciting grammar in EC, however, 57.6\% of students in CC spent much more time on oral English exercise; from question 3, more than half of the students in EC considered that communicating with English is a very difficult task, in CC, 68.4\% student regard oral English as an easy task; $71.7 \%$ of them think their oral English level is low in item 4; item 5 revealed that $55.3 \%$ of students think they do not like English class in EC, but in CC, most of students like attending English class. Obviously in item 6, the above analyses show that nearly half of the students cannot participate in English class actively; item 7 exposed that in English class or their spare time, more than half of students in EC had no or little confidence in English listening, and they do not want to listen to English tapes; the account can be up to $90 \%$; item 8 is designed to know how most students spend their free time, most of them do not watch English movies, TV and animation, and the account can be up to $90 \%$; from the item 9, only $3.5 \%$ of student in EC often use equipment to exercise oral English, in CC, nearly half of students use them; item 10 revealed that only $2.1 \%$ of students are willing to participate in the English activities, most of them are afraid of speaking English in public, but students in $\mathrm{CC}$ enjoy becoming the numbers of English speech contest. The above analyses show that most of students do not have much interest and enough confidence in speaking English, and students' oral English in rural middle school is worse than students in city. In many times, they are not willing to participate in the English class and activities

The different questionnaire was conducted in teachers of Grade 7 in both schools, and the following data were collected from the teachers' answers to the 10 items in the questionnaire. 
TABLE 4.2.2.2

THE RESULTS OF THE QUESTIONNAIRE IN FOR TEACHERS

(XL=Xibnli middle school; $\mathrm{ZC}=\mathrm{Zhaocheng}$ middle school; $\mathrm{A}, \mathrm{B}, \mathrm{C}$ choice items)

\begin{tabular}{|c|c|c|c|c|}
\hline Item & Class & $\mathrm{A}(\%)$ & $\mathrm{B}(\%)$ & $\mathrm{C}(\%)$ \\
\hline \multirow[t]{2}{*}{1} & $\mathrm{ZC}$ & 3.5 & 40.5 & 56 \\
\hline & XL & 60.3 & 22.8 & 16.9 \\
\hline \multirow[t]{2}{*}{2} & $\mathrm{ZC}$ & 4.2 & 20.6 & 75.2 \\
\hline & $\mathrm{XL}$ & 51.6 & 35.6 & 12.8 \\
\hline \multirow[t]{2}{*}{3} & $\mathrm{ZC}$ & 4.1 & 30.5 & 65.4 \\
\hline & XL & 64.4 & 29.2 & 6.4 \\
\hline \multirow[t]{2}{*}{4} & $\mathrm{ZC}$ & 5.3 & 25.6 & 69.1 \\
\hline & $\mathrm{XL}$ & 69.1 & 24.7 & 6.2 \\
\hline \multirow[t]{2}{*}{5} & $\mathrm{ZC}$ & 10.6 & 34.5 & 54.9 \\
\hline & XL & 67.3 & 23.5 & 9.2 \\
\hline \multirow[t]{2}{*}{6} & $\mathrm{ZC}$ & 9.7 & 36.9 & 53.4 \\
\hline & XL & 67.4 & 24.4 & 8.2 \\
\hline \multirow[t]{2}{*}{7} & $\mathrm{ZC}$ & 70.6 & 10.3 & 19.1 \\
\hline & XL & 9.3 & 76.2 & 14.5 \\
\hline \multirow[t]{2}{*}{8} & $\mathrm{ZC}$ & 50.1 & 25.5 & 24.4 \\
\hline & $\mathrm{XL}$ & 16.8 & 46.7 & 36.5 \\
\hline \multirow[t]{2}{*}{9} & $\mathrm{ZC}$ & 3.4 & 30.1 & 66.5 \\
\hline & XL & 49.7 & 35.2 & 15.1 \\
\hline \multirow[t]{2}{*}{10} & $\mathrm{ZC}$ & 3.1 & 24.9 & 72 \\
\hline & XL & 60.4 & 29.6 & 10 \\
\hline
\end{tabular}

Table 4.2.2.2 shows that oral English teaching is obviously different in the two schools. Item 1 reveals that $56 \%$ of teachers think that their oral English level is low, but most of the teacher in XL think they are good at oral English; and $88 \%$ of them hardly speak English in class; in item 3, only $4.1 \%$ of teachers often exercise oral English by English taps and English movies, however, in XL, more than half of teachers do that; they considered oral English a unnecessary part in the process of learning English and it account up to $69.1 \%$; item 5 revealed that just $10.6 \%$ of teachers will encourage their students to exercise oral English, however, $67.3 \%$ of teachers in XL think it is very important to improve oral English; for the item 6, nearly half of teachers do not arrange listening and speaking exercise in English class, differently, most of teachers in XL usually put them in English class and practice more; and from item 7, compared with the teachers in $\mathrm{XL}$, in $\mathrm{ZC}$, many teachers often pay more attention to making great progress and want their students to get higher scores; a majority of the teachers in ZC claimed that the knowledge of grammar is much more significant than oral English for students in item 8; only 3.4\% of teachers think that students with good oral English will perform much better than other students, but nearly half of teachers in XL regard oral English as an effective method to improve students' real ability; from the item 9, when asked whether English speech contests will be held in class or school, most teachers said they prefer to let students remember words or passages rather than hold the activities. Comparing Table4.2 with Table4.3, it is obvious that in rural places, oral English teaching has some problems, including external and internal factors, such as teachers' teaching level, students' psychological aspects and the environment around rural places.

\section{Analysis of the Interview}

When asked how you evaluate your Oral English Teaching, one teacher in Zhaocheng Middle School said "I am not good at oral English teaching, and I think the traditional method can improve scores". However, a teacher in Xinli Middle School said "I think this is a good way to have a try". Another question is about what you do in Oral English Teaching. One teacher of Zhaocheng Middle School told "I hardly have special part in class to train oral English". On the contrary, one teacher in Xinli answered this question "I always spent much time on oral English training". How about students' attitude towards Oral English Learning? Students of the two schools have different views. One in Zhaocheng thought "I am very afraid of speaking English in class, because my oral English is poor". One student in another school believed "Oral English is very important for us to improve English ability".

From the interview, the students in the experimental class are afraid of speaking English, and they think that oral English is not much more important than English words and grammar. The time that they contribute to oral English learning is limited, even in English class. In the school, a small number students speak English, and not often. Students cannot hear normative oral English, because they do not have necessary equipment and their teachers are not able to speak English well. So the campus environment of oral English learning is insufficient. Moreover, students do not like their teachers' traditional teaching method, and they are willing to learn English by watching English movies, TV and cartoon. More importantly, they think that learning English by the traditional method is very boring and cannot really improve their English ability.

In the interview, 10 teachers of Grade 7 in the Second Middle School of Zhaocheng think that their oral English level is a little low, they admit that they are not able to speak English well. And in addition to that, teachers always pay much more attention to students' scores, so they just want students to memorize mechanically the grammar and sentences. In class, they neither speak English, nor encourage students to speak English as much as possible. What's more, in school, there are no multi-media or English equipment even they intend to help students exercise oral English. 


\section{RESUlTS AND DisCUSSION}

\section{A. The Analysis of Factors Influencing Oral English Level}

Based on the Input Hypothesis, the author found that Xinli Middle School has many effective ways to learn oral English. Teachers will speak English in class and they will pay much attention to the listening and exercise parts; teachers and students may use multimedia and speech classrooms to listen standard oral English; in addition, after class, they will take part in some English activities, English speech, contest and so on. According to the Input Hypothesis, for students in city middle school, they accept much more information when they learn English. But in rural middle school, students have no necessary equipment to learn standard English, and teachers with poor oral English cannot teach right pronunciation to students. Students cannot input adequate information to their minds. Thus, there are some differences between them.

\section{Despising the Oral English Training}

Affected by the traditional teaching mode and influence of exam oriented education, there has been a phenomenon that much attention has been paid by writing rather than listening and speaking. The motivation of English learning for many students is to cope with the high school and college entrance examinations. However, those kind of English tests are mainly check students' English reading ability, but the listening part of the total score accounts for $10 \%$,which makes teachers and students pay little attention to listening and speaking.

Through the actual research survey, there are quite a number of teachers who still use the traditional English teaching mode in English teaching. They just focuses on imparting knowledge of English grammar in class, and students just passively accept what the teacher taught, so they recite the text, remember words and sentences and take notes in class. Students and teachers just pay much attention to reading and writing skills, but ignored the importance of oral English exercise. This will make English teaching so dull and students have no interest while learning English.

\section{The Limitation of Teachers' Quality}

Through the oral English test, the author found that most of English teachers in rural middle school have poor oral English, and their professional skill is insufficient. They cannot speak fluent English in class, even the pronunciation. The wrong pronunciation that has taught in class will produce deep influence for students. It is very difficult for them to correct the wrong pronunciation. The questionnaire and interview show that most of teachers teach class in Chinese. Furthermore, they just pay much attention to grammar, words and sentences and they did not encourage students to speak English, even in class. Besides, though the new curriculum reform requires that teachers and students should take oral English seriously, they hardly introspected themselves.

\section{The Lack of English Environment}

Language learning cannot leave the language environment, but most rural middle school students in most rural area only learn English in the classroom. After English class, they rarely have time to review the knowledge what have learned. Thus, students cannot fully exercise their oral English. According to the survey, the author found that students have few opportunities to participate in English practice, such as English debate, English contest or English corner. In English class, teachers just focus on the grammatical emphasis and ignore the oral English parts. There is no listening exercise in class, so students cannot hear standard English.

However, the improvement of spoken English needs much more exercise. For them, it is very difficult to open mouth. In addition, local government pays a little attention to the oral English teaching, so the investment to oral English teaching is far more adequate. The school is not equipped with English teaching resources, such as multimedia, speech classrooms and so on. Thus, students cannot accept standard oral English. From the view of the students, most of the villages and rurals school students have formed a psychological disorder due to the few opportunities to exercise oral English, and they also dare not to or be willing to speak English.

\section{B. Suggestions to Improve Oral English Ability}

\section{Taking the New Method of Teaching English}

Importantly, teachers and students should pay much attention to oral English.

As for students, they should spend much more time in listening and speaking English. At spare time, students can listen to English taps and imitate the pronunciation in taps. Exercise is the best way to improve spoken English. In order to improve the courage of speaking English, they may chat with others as much as possible by simple conversations.

As for teachers, firstly, they should try their best to speak English in class and pay much attention exercise conversations and listening parts in textbook. Secondly, teachers are supposed to encourage students speak English in class as much as possible. For example, they can ask students to talk English conversations in groups and correct their wrong pronunciation. Thirdly, teachers can organize oral English activities and encourage students to take part in, such as, English contest, English corner and English debate, which can stimulate their interests for learning English and help them overcome the psychological disorder. Lastly, there should be spoken English test system in schools. Teachers should test students' oral English and make students take oral English seriously. Through this test system, students will try their best to practice spoken English.

\section{Improve the Professional Quality of English Teachers}

The role of teachers in the teaching process is mainly to lead the road of education, in another words, they pass basic knowledge to students, which requires teachers to have a certain professional skills and ability. English teacher is the 
developer and designer of the English curriculum, and they play an important role in the way of improving students' quality. The professional quality of English teachers has a direct impact on the English teaching effect.

First of all, English teachers should have good professional quality, especially the ability of spoken English teaching. So schools provide opportunities for English to re-education and regular oral English training and arrange English teachers to listen lessons thought by excellent English teachers. They need read a large number of books and attend lectures about English teaching to develop themselves.

\section{Support from the Government and the Education Institution}

The problem of spoken English teaching has existed for a long time, but this cannot draw enough attention for English teachers to improve themselves. In order to completely solve the problem, it also needs the strong support of the government and the society. They can formulate relevant policies to encourage a higher quality of English major students to go to the countryside and select good spoken English teachers to the schools and give them suggestions, which can promote the exchange English teaching activities for the urban and rural schools. In addition, the government should organize regular oral training and encourage teachers in rural schools take part in phonetic learning.

Besides, the government should solve the problem of teaching conditions and outdated equipment, improve the teaching facilities, increase rural teachers' personal income and provide more infrastructures for these schools, such as, multimedia, speech classrooms and so on. On the other hand, education institution should encourage college graduates to develop in counties and promote their living conditions, making the structure of teaching more reasonable.

\section{CONCLUSION}

In middle schools, oral English teaching is an important part in the whole process of the English teaching and is generally a developing topic for education circle. Because of the influence of several factors in oral teaching environment, for example, the English teachers' professional qualities and the students themselves, oral English teaching in rural middle school cannot always get great progress. With the development of new curriculum reform, what the rural middle school should do is an urgent task. In addition, how to deal with the problems in oral English teaching and to seek the breakthrough and innovation in spoken English teaching is a question that needs us to think seriously.

This paper investigates oral English teaching in rural middle school and gets conclusion as follows: Rural oral English teaching is mainly affected by the external teaching environment, limitation of the traditional mode and professional quality of English teachers. In view of the existing problems, the author lists the related English teaching strategies and suggestions in this paper. Through the analysis of the survey results, this paper puts forward to the feasible solutions. On the one hand, the most fundamental way is to resolve teachers' own development in rural and to improve their teaching qualities. On the other hand, the improvement of oral English teaching in rural middle schools also needs support of manpower and material from the government and the department of education. With the support of the government and the society, the communication between urban and rural schools will increase, and gradually, the oral English teaching in rural places will become better and better.

\section{APPENDIX I}

The Listening Test of the First Term Exam in Zhaocheng Middle School

A. Listen and choose what you hear.
( ) 1. A raining
B watching
( ) 2. A Toronto
B Moscow
C playing
( ) 3.A weather
B windy
C Cairo
( ) 4.A I'm thing
( ) 5.A between
B I'm drinking C I'm looking
B behind
$\mathrm{C}$ before

B. Listen to dialogues and write down the right answers.

( ) 1. What day is it today?
A Friday B Saturday

( ) 2. Where is the pay phone?

A It's next to the library B It's next to the supermarket.

C It's across from the supermarket.

( ) 3. What's Jim doing?

A He's reading B He's watching TV. C He's playing computer game.

( ) 4. What does Bill want to be in the future?
A teacher
B An actor
C A driver

( ) 5.Where are they talking?

A In the library $\mathrm{B}$ on the street

$\mathrm{C}$ across from the school D Listen and choose

( ) 6. What does John do?

A He is a teacher B He's a cook. C He is a worker.

( ) 7.What does he speak? 
A Chinese B English C A and B

( ) 8.How does he think about his work?
A It's exciting
B It's interesting.
C It's delicious.

( ) 9.Does he like people to eat his food?
A Yes, he does
B No, he doesn't

( ) 10. How do you think of his food?

A It's delicious B It's interesting C It's cold.

C. Listen and repeat

apple banana orange grape lemon mango

dog pig rat snake cat bird

Good morning everyone, my name is Jiming.

I often go to school on foot.

My favorite subject is English, and you?

I want to be a great teacher in the future.

APPENDIX II

The questionnaire for teachers

1. What do you think of your ability of the spoken English?

A great B so-so C bad

2. Do you speak English in your class?

A always B sometimes C hardly

3. Do you exercise your spoken English?

A always B sometimes C hardly

4. Do you think it is important to learn spoken English?

A yes B so-so C no

5. Do you encourage your students to exercise spoken English?

A always B sometimes C hardly

6. Is there any part about listening and speaking in your English class?
A always
B sometimes
C hardly

7. What do you think the purpose of learning English?

A make good grades B communicate in English C broaden horizons

8. Do you think which one is more important? Grammar or oral?

A grammar B oral C both

9. Do you think the spoken English is helpful to the study of English?

A yes B a little C no

10. Will you hold English speech contest regularly?

A yes B sometimes C no

\section{APPENDIX III}

The questionnaire for students

1. Do you usually speak English?
A yes
B sometimes
C hardly

2. Do you spend much time remembering words and grammar?
A yes
B sometimes
C no

3. Can you communicate in English?

A yes B sometimes C no

4. What do you think oral English proficiency?
A great
B so-so
$\mathrm{C}$ bad

5. Do you enjoy your English class?
A yes
B so-so
C no

6. Do you usually take part in English class positively?
A yes
B sometimes
C no

7. Do you usually exercise listening?
A yes
B sometimes
C no

8. Do you usually watch English movies or cartoons?
A yes
B sometimes
$C$ hardly

9. Do you exercise oral English equipped in schools?

A yes B sometimes C hardly

10. Do you usually take part in English speech contest or debate? 
A yes B sometimes C hardly

\section{APPENDIX IV}

The interview for teachers

1. How do you evaluate your general situation about oral English teaching?

2. What's your attitude of Oral English Teaching

3. What do you do in oral English teaching?

4. What's your campus environment of teaching oral English?

\section{APPENDIX V}

The interview for students

1. What's your attitude of Oral English Learning?

2. What do you do in Oral English Learning?

3. What's your campus environment of learning oral English?

4. What's your favorite Oral English Learning method?

\section{ACKNOWLEDGMENTS}

The four-year college will be finished, and I have a happy and substantial life in Yuncheng University. Here I want to take this opportunity to thank those who give me much help in the process of writing the paper.

At First, I would like to show my gratitude to all of my teachers over these four years, but especially to my adviser Zhi Weihua, for his professional help and instructions. Without his help, I would not finish the thesis favorably. In the process of writing thesis, he gave me much help in studies and life and taught me something important. I will never forget all of those.

Secondly, I want to express my appreciation to all of teachers and students who help me to finish the questionnaires and interviews in Zhaocheng Rural and Linfen City, especially to Wang Haiyan, my middle school English teacher. She tried his best to help me contact interviewees.

Thirdly, I want to express my gratitude to all my friends here especially to classmates, for their guidance in the process of literature review and data analysis.

And finally, I want to thank my parents for their supporting and kindness. There are too many people I should express my gratitude and I will never forget them. I will keep my passion for studies and make much progress in the future.

\section{REFERENCES}

[1] Alexander, L.G. (1996). An Attempted Murder. English Language Learning, (6):92-93.

[2] Cheng, R.R. (2012). A Study on the Present Situation and Countermeasures of Oral English Teaching in Rural Primary and Middle Schools. Chongqing Normal University.

[3] Gao, H.H. (2006). How to Develop Oral English Teaching for College Students. Audio-visual Foreign Language Teaching, (76):3-6.

[4] Gillian Brown. (2001). The Future of English. English Language Learning, 2001(01):29-30.

[5] Hu, Q.H. (2012). The Exploration of Oral English Teaching in Rural Middle School. Academic Research, (5):40-42.

[6] Huang, B.W. (2011). Problems and Solutions of Spoken English in Rural Middle Schools. Success (Education), (5):50-51.

[7] Hymes, D. (1972). On communicative competence. In J.B. Pride and J. Holmes, (4):110-114.

[8] Jeremy Harmer. (2000). How to Be a Good Teacher. Basic Educational Research on Foreign Language Teaching, (5): 46-49.

[9] Krashen, S. D. (1985). The Input Hypothesis: Issues and Implication. London: Longman.

[10] Krashen, S. D. (1989). Language Acquisition and Language Education. Oxford: Pergamon Press Ltd.

[11] Liu, R.Q., \& Han, B.C. (2008). Review and Reflection on English Education in Basic Education in China. Foreign Language Teaching and Research, (2):150-156.

[12] Nunan, D. (1999). Second Language Teaching and Learning. Beijing: Foreign Language Teaching and Research Press.

[13] Paulston, C. B. \& Bruder, M. N. (1992). Teaching English as a Second Language: Techniques and Procedures. Cambridge: Cambridge University Press.

[14] Sun, L.F. (2008). A feasible Experiment on Improving Students' Oral Ability in Rural High Schools in Hebei Province. Huazhong Normal University.

[15] Thomas S. Ellis. (1985). The Effects of Irradiation on the Thermal Properties of Semi-crystalline Polyamides. Chinese Journal of Polymer Science, (3):127-129.

[16] Wang, L.F. (2000). Modern Foreign Language Teaching Theory. Shandong: Shandong University.

[17] Wen, Q.F. (1998). Evaluation of Oral Language Teaching in Language Laboratory. Foreign Language World, (1):30-33.

[18] Zhang, M.Y. (2015). Problems and Countermeasures in Oral English Teaching in Rural Middle Schools. Northeast Normal University.

[19] Zhang, Z.Y. (2006). The Cultivation of Students' Oral Communicative Competence. Educational and Scientific Research Forum, (6):50-51. 
Yayan Yu was born in Linfen, China in 1992. She received her bachelor's degree in English teaching from Yuncheng University, China in 2016.

She is currently an assistant in Modern College of Humanities and Sciences of Shanxi Normal University, Linfen, China. Her research interests include English teaching and linguistics.

Ms. Yu got a second prize scholarship and a prize of excellent student during the study for a master degree. 